\title{
ABBREVIATIONS
}

ABZ Arbeit in Bild und Zeit

AEAR Association des Écrivains et Artistes Révolutionnaires

AIZ Arbeiter Illustrierte Zeitung (Workers' Illustrated Magazine)

BIZ Berliner Illustrirte Zeitung

DNVP Deutschnationale Volkspartei

ECCI Executive Committee of the Communist International

FIFO Film und Foto exhibition

IB Illustrierter Beobachter

KPD Kommunistische Partei Deutschlands

NDV Neuer Deutscher Verlag

RFB Roter Frontkämpferbund

RPL Reichspropagandaleitung (Reichs Propaganda Ministry)

SA Sturmabteilung

SdP Sudetendeutsche Partei

SPD Sozialistische Partei Deutschlands

SS Schutzstaffel

UWW Unser Wille und Weg

VI Die Volks Illustrierte 


\section{S.M. ADOLF}

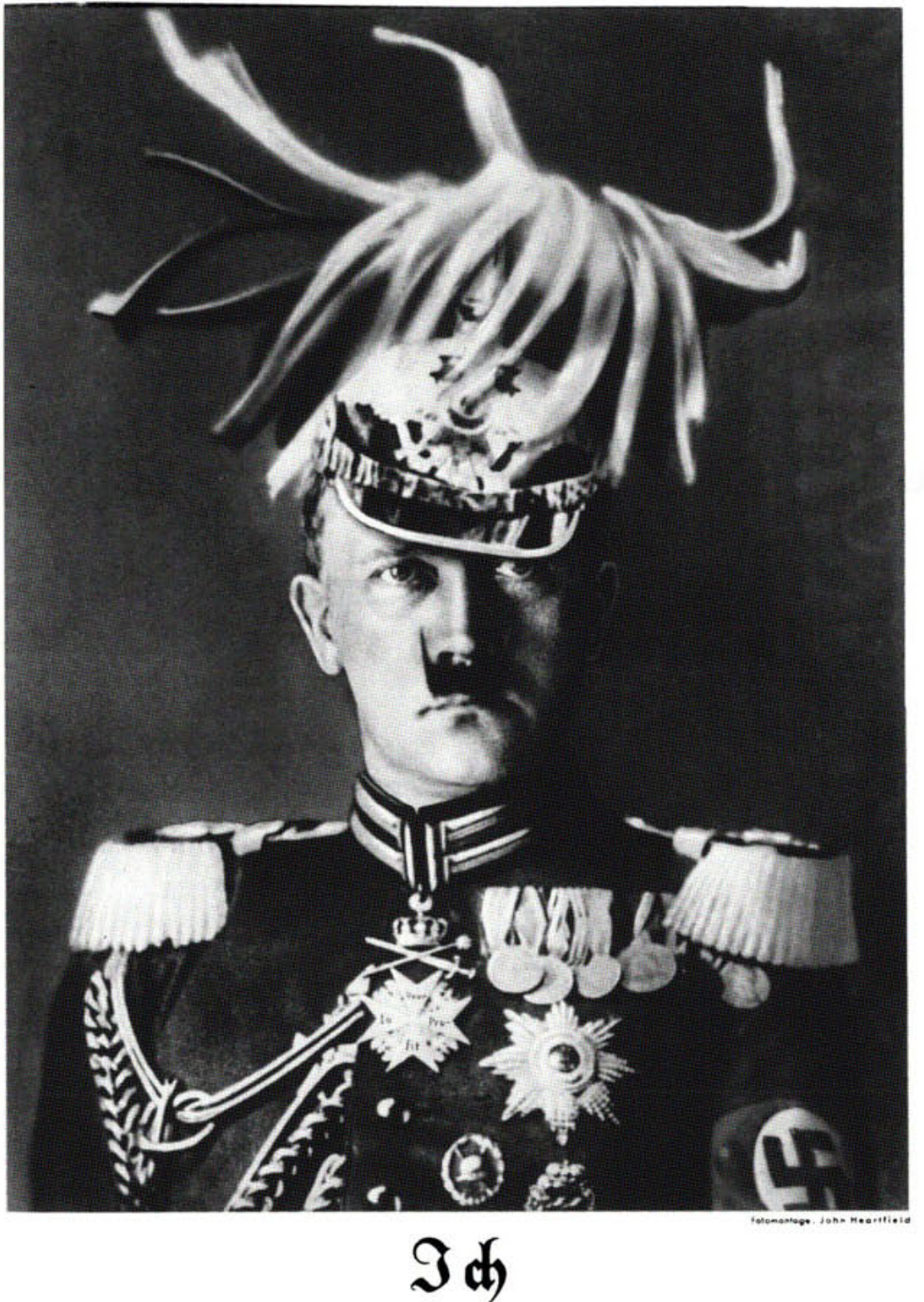

führe Eud herrliden Bleitenentgegen!

FIGURE 1 .

John Heartfield, His Majesty Adolf, from AIZ II, no. 34 (August 21, 1932). The Getty Research Institute, Los Angeles (87-Si94). (C) IVARO/VG Bild-Kunst, Bonn. 